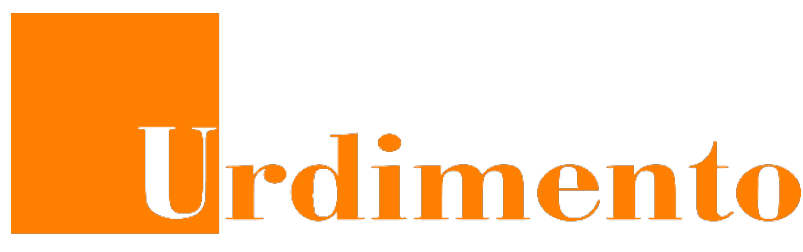

REVISTA DE ESTUDOS EM ARTES CÊNICAS E-ISSN 2358.6958

\title{
Ateliê de cenografia: Aprender-ensinar em tempo de pandemia
}

\author{
André Sanches Sampaio
}

Para citar este artigo:

SAMPAIO, André Sanches. Ateliê de cenografia: Aprender-ensinar em tempo de pandemia. Urdimento Revista de Estudos em Artes Cênicas, Florianópolis, v. 3, n. 42, dez. 2021.

doi DOI: http:/dx.doi.org/10.5965/1414573103422021e0110

Este artigo passou pelo Plagiarism Detection Software | iThenticate 


\title{
Ateliê de cenografia: Aprender-ensinar em tempo de pandemia ${ }^{1}$
}

\author{
André Sanches Sampaio²
}

\begin{abstract}
Resumo
O presente trabalho reflete sobre questões, inquietações e estratégias de ensino reveladas durante a experiência do ensino emergencial remoto, provocada pela pandemia mundial da COVID-19, no contexto da disciplina Ateliê de Cenografia II, do Departamento de Cenografia da Escola de Teatro da Universidade Federal do Estado do Rio de Janeiro. Em tempos tão desafiadores, a arte, com toda sua potência, possibilitou um movimento dialógico e de construção coletiva fortalecendo vínculos, escuta, criação e invenção. Afinal, o que podem gestos, muitas vezes mínimos, de atenção às singularidades e diferenças? O que pode uma relação de aprendizagem aberta aos encontros? O que podem os encontros?
\end{abstract}

Palavras-chave: Pandemia. Ensino remoto. Artes cênicas. Cenografia.

\section{Scenography Workshop: Learning-teaching in a time of pandemic}

\begin{abstract}
The present work reflects on questions, concerns and teaching strategies revealed during the experience of remote emergency education, caused by the global pandemic of COVID-19, in the Stage Design II discipline, which is part of the curriculum of the Scenography Department of the School of Theater at the Federal University of the State of Rio de Janeiro. In such challenging times, art, with all its power, enabled a dialogic movement and collective construction, strengthening bonds, listening, creation and invention. After all, what can gestures, often minimal, of attention to singularities and differences do? What can a learning relationship that is open to encounters do? What can such encounters do?
\end{abstract}

Keywords: Pandemic. Remote teaching. Performing arts. Scenography.

1 Revisão ortográfica e gramatical do artigo realizada por Tiago Ribeiro. Professor vinculado ao Instituto Nacional de Educação de Surdos (INES) e ao Programa de Doctorado en Educación de La Facultad de Humanidades y Artes de la Universidad Nacional de Rosario/Argentina.

${ }^{2}$ Mestre em Artes Cênicas pela Universidade Federal do Estado do Rio de Janeiro (UNIRIO). Professor do Curso de Bacharelado em Cenografia e Indumentária do Departamento de Cenografia do Centro de Letras e Artes da Escola de Teatro, da Universidade Federal do Estado do Rio de Janeiro (UNIRIO). andre.sampaio@unirio.br (9) http://lattes.cnpq.br/8404081378259298 (iD) https://orcid.org/0000-0002-6571-259X 


\section{Taller de escenografía: Aprendizaje-enseñanza en tiempo de pandemia}

\section{Resumen}

El presente trabajo reflexiona sobre interrogantes, inquietudes y estrategias de enseñanza reveladas durante la experiencia de educación emergencial remota, provocada por la pandemia mundial de COVID-19, en el contexto de la disciplina Estudio de Escenografía II, del Departamento de Escenografía de la Escuela de Teatro de la Universidad Federal del Estado de Rio de Janeiro. En tiempos tan desafiantes, el arte, con todo su poder, posibilitó un movimiento dialógico y una construcción colectiva, fortaleciendo vínculos, escucha, creación e invención. ¿Qué pueden los gestos, a menudo mínimos, de atención a las singularidades y a las diferencias? ¿Qué puede una relación de aprendizaje abierta al encuentro? ¿Qué pueden los encuentros?

Palabras clave: Pandemia. Enseñanza a distancia. Las artes escénicas. Escenografía . 


\section{Apresentação}

[...] a invenção do hoje é o meu único meio de instaurar o futuro.

(Clarisse Lispector, 2019)

Através das experiências vivenciadas em minha prática docente, durante o período de isolamento social imposto pela COVID-19 procuro, nesta escrita, reverberar questões que me provocam inquietações e, sobretudo, a refletir sobre as estratégias de ensino diante dos novos desafios revelados neste momento de dúvidas e incertezas.

A pandemia da COVID-19, pelo novo coronavírus (SARS-CoV-2), apresentouse como um dos maiores desafios deste século. Ocasionou enorme crise sanitária, econômica, política e educacional em todo o mundo, levando à morte milhares de pessoas. Nessas circunstâncias, vimo-nos forçados a entrar em isolamento social, como medida preventiva para a contenção da infecção. Comércio, indústria e serviços tiveram suas rotinas alteradas. Não foi diferente com as escolas e universidades, que, logo após o início do ano letivo de 2020, suspenderam as atividades presenciais.

Com a realidade da pandemia, os/as professores/as foram obrigados/as a reestruturar seus processos didáticos, tipos de aulas ministradas, propostas de exercícios, monitoramento do aprendizado e formas de avaliação. Esbarraram, inesperadamente, na necessidade de uma atividade educacional totalmente diferente, complexa, pouco conhecida, com regras e fazeres indefinidos. Foi necessário a readequação das velhas posturas ao novo cotidiano, através da revisão das fórmulas tradicionais, total ou parcialmente. Entretanto, fazer de outro modo, distanciando-nos das formas habituais de aprender-ensinar, é sempre um desafio. Como fazer? Por onde começar?

Sou professor, há sete anos, do curso de Bacharelado em Cenografia e Indumentária da Escola de Teatro do Centro de Letras e Artes, da Universidade Federal do Estado do Rio de Janeiro (UNIRIO). No movimento de pensar e repensar 
modos que vêm me constituindo professor, abriguei e descartei ideias, formulei e testei hipóteses, construí e refutei teorias, proferi e recebi críticas, sempre almejando compreender melhor o meu próprio ofício e aperfeiçoá-lo. Descobri que venho me formando professor com os/as estudantes. Descobri a docência com eles e elas; uma docência inscrita em um tempo outro; uma docência da experiência e, também posso dizer, uma experiência da docência. E, para chegarmos a ela, precisamos sair do lugar, nos expormos, pormo-nos a caminhar. A docência enquanto força instauradora do novo, como potência que inaugura sentidos, que pulula perguntas e abre possibilidades para pensar o pensamento.

Esta compreensão, "se aproxima e potencializa o que defendo como formação docente, enquanto experiência que nos atravessa, desestabiliza e oferece outros modos de sermos professoras e professores. Uma formação outra que rasga o que nos habita, apontando desvios e caminhos que nos tiram do lugar" (Lima, 2018, p.314). Uma perspectiva de formação de mãos dadas com a arte, logo, no campo da complexidade, da criação, da invenção e da transgressão.

\section{Ensino remoto? "Novo normal"? Crise como oportunidade de inovação?}

Não pretendemos que as coisas mudem, se sempre fazemos o mesmo.

A crise é a melhor benção que pode ocorrer com as pessoas e países, porque a crise traz progressos. A criatividade nasce da angústia, como o dia da noite escura. É na crise que nascem as invenções, os descobrimentos e as grandes estratégias. [Albert Einstein (1879-1955)]

Estávamos no quinto dia do início do ano letivo de 2020, quando as atividades presenciais na UNIRIO foram interrompidas. Fomos compelidos a entrar em isolamento social como prevenção para a contenção da pandemia, adotado com mais ou menos compromisso e seriedade, conforme entendimento de cada governo municipal ou estadual, tendo em vista o descaso do governo federal no que tange ao enfrentamento da COVID-19. Nossos primeiros sentimentos eram de 
dúvidas e descrença.

De acordo com as orientações das autoridades sanitárias, o calendário acadêmico de 2020 foi suspenso no dia vinte e quatro de março. O que imaginávamos ser um momento breve, de curta duração, foi redimensionado. Após arrastadas semanas de perplexidade e paralisia, era urgente a tomada de atitudes em busca da adequação perante o caos. Toda comunidade acadêmica esperava por notícias efetivas em meio a especulações, aguardando o resultado de cada reunião que ocorria entre as instâncias superiores da universidade, direções, coordenações, chefias e colegiados de cursos.

Vale ressaltar que fui coordenador do curso de Bacharelado em Cenografia e Indumentária até março de 2021. Vivenciei de perto todas as discussões e reuniões. Eram tantos detalhes e empecilhos que parecia impossível vislumbrar uma solução possível. Termos desconhecidos da maioria dos/as professores/as invadiam nosso vocabulário: ensino remoto, atividades síncronas e assíncronas, lives, podcast, entre outros, até então restritos ao universo da educação à distância (EAD), tornaram-se populares.

Mas, como planejar nesse "novo normal", onde "O isolamento social, necessário para impedir a expansão da infecção por Covid-19, fez com que as atividades presenciais nas instituições educacionais deixassem de ser o normal" (Strauhs; Tedeschi, 2021, p.28)? Como reagir à quebra de paradigma do ensino presencial, para repentinamente adotar o ensino remoto? Qual a implicação dessa mudança?

A expressão ensino remoto passou a ser usada como alternativa à educação a distância (EAD). Isso porque a EAD já tem existência estabelecida, coexistindo com a educação presencial como uma modalidade distinta, oferecida regularmente. Diferentemente, o ensino remoto é posto como um substituto excepcionalmente adotado neste período de pandemia, em que a educação presencial se encontra interditada (Galvão; Saviani, 2021, p.38).

O ensino remoto consiste na "adaptação de aulas que, em sua origem, são presenciais, mas que, pela emergência da pandemia, tiveram de ser transmitidas à distância" (Ribeiro, 2020, p. 474). Neste sentido, o que considerar imprescindível no planejamento do ensino remoto para estudantes da universidade pública? 
Quais conhecimentos priorizar para que se propicie uma aprendizagem mais significativa? Como contornar o receio dos/as professores/as com a mudança de paradigma que sempre lhes garantiu segurança?

Para a grande maioria dos/as professores/as, essa experiência seria o primeiro contato com atividade de ensino virtual. O sistema educacional,

[...] está acostumado a pouca - ou quase nenhuma - mudança de status quo, sendo que sua atuação tradicional ainda perdura, mesmo passados vários séculos, bem como movimentos de renovação pedagógica e metodológica. Podemos dizer que a educação é uma instituição que salvaguarda as tradições, com algumas (poucas) modificações ao longo da trajetória histórica da humanidade, demonstrando algumas mudanças de posturas e percursos, sobretudo ao longo do século XX, mais precisamente na sua segunda metade (Oliveira, 2020, p. 247).

Entretanto, devido às circunstâncias, as estruturas tradicionais precisavam ser inevitavelmente modificadas. Era necessário repensar as interações nas formas de perpetuação da relação entre ensino e aprendizagem. Nessa perspectiva, foi sendo, aos poucos, planejado um modo pelo qual a universidade pudesse se programar para que seu calendário acadêmico fosse retomado através do ensino remoto, à distância.

A possibilidade do ensino remoto provocou um enorme receio no corpo docente e discente. Entre muitas reuniões, infindáveis discussões e inúmeros detalhes, a perspectiva, a priori, era de que não seria plausível realizar o ensino à distância. Os impedimentos pareciam infinitos. Como ministrar as disciplinas práticas? E as teórico-práticas? O que fazer com os estágios? Como garantir aos/às estudantes acesso adequado à internet? A constante lembrança de que os cursos eram presenciais, de que os/as docentes não foram preparados para o modelo de aula à distância, da falta de confiança nessa modalidade de ensino, dentre tantas outras argumentações, instaurou grande insegurança coletiva.

Apesar da enorme lista de impossibilidades, vagarosamente o planejamento avançava, com a superação dos entraves. Aproveitou-se esse período para a realização, junto aos estudantes e professores, de levantamento de informações para elaboração de propostas com vistas à redução dos prejuízos. 
Reitoria, direções e coordenações de cursos produziram pesquisas com o objetivo de mapear as condições de saúde, acesso à internet e equipamentos eletrônicos dos corpos discente e docente. Como coordenador, achei importante ligar e tentar falar pessoalmente com os/as estudantes do curso de cenografia. Gostaria de verificar como estavam e propiciar "oportunidade de fala", saber o que sentiam e pensavam, quais atividades estavam realizando, além de informar sobre as notícias das reuniões em relação ao planejamento do retorno das atividades. Consegui fazer contato e conversar com aproximadamente setenta por cento do corpo discente. As reações eram de espanto e alegria, pois não esperavam uma ligação, um acolhimento para escutá-los/as de maneira carinhosa e afetiva, apesar de tanta ansiedade.

Os depoimentos eram bem variados, mas a tônica era a saudade, tanto dos/as docentes quanto das atividades presenciais, já que a grande maioria se encontrava em casa, sem nenhuma ocupação. Problemas familiares e financeiros também eram muito recorrentes. Confesso que, por diversas vezes, fiquei comovido em razão de perceber o quanto o que narravam era profundamente verdadeiro e triste, simultaneamente. A alegria em se sentirem ouvidos era revigorante, tanto para eles/as, quanto para mim. A partir do relato dessas conversas, alguns professores/as resolveram promover encontros, rodas de conversas ou indicar cursos, palestras e vídeos, tudo online, para que os/as estudantes pudessem desenvolver alguma tarefa enquanto o Plano de Atividades Acadêmicas e Administrativas para o período de excepcionalidade, em virtude da pandemia de COVID-19, não era aprovado.

A Direção da Escola de Teatro da UNIRIO, que reúne cinco cursos de graduação em Teatro $^{3}$, realizou um questionário bastante completo sobre o perfil dos corpos discente e docente, com questões sobre meios de transporte, saúde física e psicológica, recursos materiais e condições para o trabalho remoto. 0 retorno da pesquisa foi de $81.3 \%$ entre os discentes e de $100 \%$ entre os docentes, os quais, além de responder às perguntas, realizaram sugestões para melhor balizar o planejamento das ações com vista ao retorno das atividades. 
O levantamento sobre as condições para trabalho remoto revelou que 97.9\% dos/as estudantes disseram possuir dispositivos eletrônicos com acesso à internet que thes permitiam realizar trabalhos à distância. Entretanto, analisando o detalhamento das respostas, 83\% listaram o Smartphone pessoal como uma de suas principais maneiras de acesso à internet. Apenas 49.7\% responderam ter computador pessoal e $24.7 \%$ declararam usar computador compartilhado. Somente dois discentes revelaram não dispor de acesso a equipamentos eletrônicos. Do ponto de vista técnico, 75.3\% consideravam que os dispositivos eletrônicos permitiriam um acompanhamento de estudo adequado, à medida que 24.5\% consideravam inadequado. Entre os principais fatores que dificultavam a realização de trabalhos remotos, os relatos variam sobre carência de equipamento adequado, deficiência de sinal de internet, falta de espaço físico, de privacidade e problema com barulho, além da dificuldade de concentração, crise de ansiedade e escassez de motivação.

Entre os/as docentes, nas questões referentes às condições para o trabalho remoto, apenas uma resposta revelou a total impossibilidade da realização de atividades à distância. Enquanto a maioria de 69.5\% considerava, do ponto de vista técnico, possuir dispositivos eletrônicos e acesso à internet que permitiam uma atuação de trabalho adequada, 30.5\% julgavam inadequada. Dentre os motivos fundamentais que dificultavam a realização de trabalho remoto, foram citados: lacuna na capacitação de ferramentas pedagógicas adequadas; receio com a qualidade de ensino; dificuldade com uso de equipamentos; resistência na adaptação de disciplinas com carga horária prática; espaço de trabalho inadequado; falta de privacidade e de concentração; sobrecarga de trabalho doméstico e cuidado com familiares. Outro ponto considerável era a preocupação com o acesso dos/as estudantes a equipamentos eletrônicos e de conexão com internet satisfatórios. O receio de que a experiência do ensino remoto possa ser posteriormente utilizada como argumento para oficializar o ensino à distância também foi lembrado. Ao serem indagados sobre a substituição excepcional de atividades presenciais por atividades à distância, 59.3\% dos/as professores/as acreditavam que isto acarretaria muito prejuízo, embora avaliassem a possibilidade. Apenas 20.3\% responderam que este recurso possibilitaria a continuidade do trabalho com pouco prejuízo, e o mesmo percentual considerava 
impossível a continuidade dos trabalhos nesta modalidade. Outro detalhe relevante da pesquisa, a ser considerado, é que $81.4 \%$ dos/as docentes relataram que lecionavam alguma disciplina com atividades práticas na Escola de Teatro.

Compreende-se, portanto, que as necessidades do mundo virtual desencadeariam novas demandas e exigências para as quais muitos não estavam preparados. Um fator importante que não pode ser desconsiderado perpassa pelas relações produzidas no interior das universidades entre corpo docente e discente, tecnologia e aprendizagem.

Historicamente, as nossas universidades padecem de maior incentivo a programas de formação, acompanhamento, diálogo dos docentes com questões de ordem didático-pedagógica, voltados para o uso de interfaces tecnológicas variadas - quadros interativos, ambientes de aula on-line, uso de plataformas com vários ambientes integrados. A expressão "não entendo nada de ambiente on-line!" chega ao cotidiano dos professores como uma representação dos distanciamentos entre o professorado e o uso de ambientes, programas, aplicativos, voltados para estabelecer relações mais naturalizadas e passíveis de diálogos sobre a necessidade de construção de ambientes remotos - isso se deve também aos limites orçamentários para construção de uma política de investimentos, para criar condições de introduzir essas vivências (Brito; Mussi, 2020, p.52).

Com o propósito de minimizar este problema e prestar as orientações básicas necessárias para dar apoio ao uso das plataformas de ensino remoto, a universidade disponibilizou e/ou indicou programas/cursos de treinamento online para os/as docentes.

Em uma perspectiva bastante prática do exercício de sua profissão, o que estamos vendo hoje são professores sendo convocados a abrirem seus computadores e trabalhar com tecnologias e aplicativos que não conheciam e que não dominavam antes da pandemia (Da Luz; Maquêa, 2020, p.110).

Numa profusão de vídeos, cursos e tutoriais, os/as docentes foram, cada um/a à sua maneira, se adequando às necessidades do momento. "Excesso de informação. Cuidados discretos com etapas e pré-requisitos” (Vilarinho Jr., 2021, p.450).

Porém, mesmo para atuar como excepcional, substituto ou emergencial, o 
ensino remoto demandava outras condições para ser colocado em prática, além da preparação dos/as professores/as em relação ao uso das ferramentas virtuais, em seus aspectos pedagógicos e tecnológicos. Uma delas era garantir aos/às estudantes acesso adequado ao ambiente virtual, através de equipamentos eletrônicos minimamente apropriados e conexão a uma rede digital de qualidade, para facilitar a participação nas aulas. Neste sentido, a universidade realizou um cadastro com a finalidade de disponibilizar bolsas para a aquisição de equipamentos e chips com plano de dados.

Diante das iniciativas institucionais em benefício do auxílio necessário para que docentes e discentes pudessem desempenhar suas funções, o Plano de Atividades Acadêmicas e Administrativas para o período de excepcionalidade, em virtude da pandemia de COVID-19, foi aprovado, enfim, pelo Conselho Universitário (CONSUNI) e pelo Conselho de Ensino, Pesquisa e Extensão (CONSEPE), no dia 17 de agosto. O documento estabeleceu diretrizes, ações e recomendações para o contexto de excepcionalidade e indicou as estratégias de ensino-aprendizagem e de trabalho remoto por meio de Tecnologias de Informação e Comunicação.

A Escola de Teatro elaborou, a partir do principal, seu próprio Plano de Atividades Acadêmicas e Administrativas para os cinco cursos de graduação em Teatro, com o detalhamento do calendário, modo de ofertas de disciplinas e critérios de matrícula. Ficou determinado que o recomeço das atividades acadêmicas em formato remoto (período excepcional), referente ao primeiro semestre de 2020, seria no dia 22 de setembro.

\section{Possibilidades inscritas nas impossibilidades...}

Toda mudança parece, num primeiro momento, ter um caráter exclusivamente utópico ou até impossivel.

Entretanto, é necessário observarmos que é exatamente nas possibilidades utópicas que se pode estabelecer um futuro no qual a sociedade possa apresentar realidades melhores do que as que temos agora.

Se, ao contrário, vemos a mudança como impossível, perdemos, então, qualquer perspectiva de humanidade.

(Marcia Moraes, 2002)

Com a aprovação do plano de atividade e a confirmação do início das aulas, 
os colegiados dos cursos da Escola de Teatro estabeleceram as disciplinas que seriam ofertadas por cada departamento. Para garantir a qualidade pedagógica do ensino remoto, visto que seria a primeira vez que a grande maioria dos/as professores/as enfrentaria este desafio, recomendou-se que os/as docentes tivessem garantido o direito de assumir apenas uma disciplina de sessenta horas, ou duas de trinta. Foi requisitado, também, a opção pela oferta de disciplinas optativas ou eletivas que pudessem, posteriormente, ganhar equivalência em disciplinas obrigatórias e cujas atividades práticas, quando necessárias, fossem passíveis de ocorrer de maneira remota, por meio de atividades síncronas e/ou assíncronas.

Tínhamos, na Escola de Teatro, uma posição clara quanto à flexibilização dos conteúdos. Que o planejamento tivesse coerência com o contexto virtual e de crise sanitária. Neste sentido, reverberavam em meus pensamentos, enquanto professor, quais seriam meus desejos e propósitos para pensar em modos de ensinar que potencializem aprendizagens, promovendo uma formação humana crítica e mantendo a relação de reciprocidade e afeto, que tanto prezo, entre estudantes e professor.

Em tempos tão desafiadores, a arte, com toda sua potência, apresentou-se como um atalho para acessarmos nossas sensibilidades humanas. Nos revelou, também, ser possível acreditar na capacidade de criação e reinvenção. Nessa lógica, me interessava buscar um caminho guiado pela formação estética, que, em vez de priorizar conteúdos e grade curricular, investisse na relação com o momento, com a vida, com os seres, as coisas e os sentidos...

\begin{abstract}
Educação estética tem relação, então, com o cultivo de todos os sentidos: aprender a refinar o olhar, a audição, para poder ver, ouvir, sentir cada vez melhor o que se está vendo ou ouvindo, aperfeiçoando a autoconsciência [...] Prestar atenção, reparar - o mundo, seus cantos, recantos e encantos; a cultura, a diversidade cultural, a arte que nos rodeia e nos olha; as relações e paisagens internas que nos habitam -, limpar os olhos, aguçar todos os sentidos, são caminhos de formação estética (Ostetto; Silva, 2018, p.193).
\end{abstract}

Sob esta perspectiva, decidi ofertar a disciplina optativa Ateliê de Cenografia I/, com equivalência às disciplinas obrigatórias Projeto Integrado em Cenografia e 
Indumentária / e Projeto Integrado em Cenografia e Indumentária II, conforme necessidade do/a discente.

O conteúdo programático do Ateliê de Cenografia é definido pelo/a professor/a, quando ocorre sua oferta. Deve proporcionar ao/à estudante o aprendizado e experimentação de linguagens relacionadas à cenografia, através do desenvolvimento de um projeto mediante leituras e exercícios práticos. Além de possuir semelhança com o conteúdo das disciplinas que seriam equivalentes, acreditava que a escolha facilitaria a seleção de temas, atividades e estratégias que provocassem o interesse, a criatividade e a reflexão. Vislumbrava, desse modo, um caminho atraente diante do momento único e incomum.

Utilizando como apoio a discussão sobre os formatos de encenação e experiências artísticas surgidas durante o período de afastamento social, que abriram uma nova janela entre artistas e público no ambiente virtual4 ${ }^{4}$ meu compromisso ético, político e estético era explorar a relação dos/as estudantes com o mundo e com o instante vivido. Que eles/elas fossem "mobilizados pela criação, recriação e vontade de modificar seu contexto, com sensibilidade e experiência" (Guimarães; Ribeiro, 2019, p.82). Pretendia, dessa maneira, que a disciplina contribuísse para ampliar a reflexão crítica sobre a cenografia como campo de ensino e de pesquisa, articulando questões e propostas com a finalidade de apresentar referências - teórico/práticas, poéticas e afetivas - que nos fortalecessem para o enfretamento dos desafios surgidos.

A plataforma digital escolhida para viabilizar o Ambiente Virtual de Aprendizagem - AVA, foi o Google Classroom, uma das plataformas institucionais da universidade. A carga horária de sessenta horas foi dividida em cinquenta por cento para atividades assíncronas ${ }^{5}$, com leituras e tarefas práticas, e cinquenta por cento com atividades síncronas ${ }^{6}$, em encontros semanais de duas horas. Tentei minimizar a falta do contato presencial e de interação social transformando estes

${ }^{4}$ Conforme o Plano de Curso da disciplina Ateliê de Cenografia II, criado para o período excepcional.

${ }^{5}$ São aquelas onde não é necessário que os/as alunos/as e professores/as estejam conectados ao mesmo tempo para que as tarefas sejam realizadas.

${ }^{6}$ São aquelas em que é necessária a participação do/a aluno/a e professor/a no mesmo instante e no mesmo ambiente - nesse caso, virtual. 
encontros, através da sala de aula virtual, em um espaço humanizador.

\begin{abstract}
Humanizar, durante o ensino remoto, corresponde a repensar atos simples: chamar pelo nome cada um dos estudantes e dar um tempinho para que respondam como eles estão a cada início de aula; a forma verbal será, ainda, sinônimo de perguntar sobre a saúde dos membros da família dos educandos de forma interessada e genuína. Dentro do contexto atual, humanizar também encontra significado quando o animal de estimação de alguém passar em frente a câmera e a aula ser interrompida para que esse seja o assunto por alguns instantes. Pode significar, também, que o professor silencie seu microfone em alguns momentos da aula, abrindo mão do "controle" e exercitando a escuta, permitindo o protagonismo do outro (Souza, 2021, p.477).
\end{abstract}

A princípio, o momento que antecedia a aula vinha sempre acompanhado por alguma ansiedade. Será que os/as estudantes vão comparecer? E se não acharem o link de acesso da sala no Google Classroom? Irão envolver-se?

Não é novidade para a educação que estar presente nem sempre é sinônimo de participação. Quando o que acontece não nos toca, quando passamos pela aula sem sermos afetados, a participação não aconteceu mesmo que estejamos presentes (Duarte; Fiss, 2021, p.488).

Entretanto, após os primeiros encontros, senti que a troca foi sendo estabelecida, superando a tela, o distanciamento e as dificuldades com a conexão de internet e equipamentos adequados.

Iniciamos as atividades com o debate sobre as formas de encenação e conexões estabelecidas, entre artistas e espectadores, em tempos de distanciamento. Introduzindo a proposta do exercício que seria desenvolvido mais adiante, trabalhamos com os relatos dos espetáculos assistidos remotamente, a indicação de vídeos/lives, a leitura de reportagens, críticas e textos publicados durante a pandemia. As narrativas compartilhadas coletivamente ajudaram os/as estudantes a se darem conta do mundo e de si mesmos(as) de modos outros. Carlos Skliar (2019, p.46-47) um professor-filósofo e poeta argentino, ressalta:

Nossas vidas são narradas por todos aqueles momentos em que "nos damos conta" [...]. Por mais que durante toda a vida nos tenham falado da importância do amor, da transcendência da leitura, da relevância da política, aprendemos somente no instante em que nos damos conta por nós mesmos, sim, de cada coisa de tudo aquilo [...]. Aprender é "dar-se conta"... 
Compreendo a narrativa de modo articulado à experiência, ao vivido, ao que marca, ao que dá a pensar, ao que imprime sentido a ponto de valer a pena ser lembrado, partilhado, contado. A narrativa pode ser fonte de implicação, de deslocamento, de ensinamento. É uma maneira não somente de conhecer, mas também de comunicar e organizar a experiência (Egan; Mcewan, 2005). Quando narramos, narramos o que nos damos conta?

Fiquei surpreso com o engajamento dos/as estudantes nos encontros. Era visível o desejo de participar e de compartilhar a realidade vivenciada.

Encontros virtuais que possibilitaram diálogos nas mais diversas áreas e em diferentes expressões do humano: demonstração de afeto, rememoração de histórias pessoais, aprofundamento de conteúdos específicos, expressão de componentes curriculares, exercício de empatia e ética, provas de gratidão, extensão do sentido de Educação (Melo; Pinto; Ribeiro, 2020, p.530).

Assumo, então, o desafio de viver a aula como acontecimento. "Tomar a aula como acontecimento é eleger o fluxo do movimento com inspiração, rejeitando a permanência do mesmo e a fixidez mórbida no passado" (Geraldi, 2010, p.100). Incorporar dúvidas, questionamentos, curiosidades, (des)conhecimentos, individuais e coletivos. Incorporar, sobretudo, perguntas, nem sempre respondidas, mas que movimentam o pensamento e o processo (permanente) de conhecer.

Desse modo, o/a professor/a é aquele/a que, mais do que transmitir conhecimentos ou informações, convida o/a estudante a se envolver com o saber, com o conhecer. Em um processo de ensino/aprendizagem, o grande desafio se encontra, para nós, no domínio dos objetivos afetivos com os quais, de um modo geral, não estamos habituados a trabalhar. Quando o fazemos, geralmente, tratase de algo meramente acidental.

Desejando tornar os encontros virtuais convidativos e interessantes, procurei trabalhar, nos momentos expositivos das aulas, com diferentes linguagens, alternando imagens, vídeos, textos e voz. Porém, não podemos negligenciar os vários imprevistos e dificuldades técnicas relacionadas à instabilidade e velocidade da conexão de internet (e, muitas vezes, a falta dela). É importante ressaltar, 
também, que alguns/mas estudantes participavam por smartphones. "Todas essas situações exigem de cada docente diferentes papéis, desde os pedagógicos e técnicos até uma alta criatividade para desempenhar sua atividade de modo a promover um ambiente de ensino adequado" (Carvalho Neta; Souza, 2020, p.212).

Com o objetivo de contextualizar o debate sobre os formatos de encenação em tempos de distanciamento e ampliar a discussão em direção ao campo do teatro contemporâneo, apresentei à turma o artigo "O Teatro Atravessado", do professor de teatro Christophe Bident, da Universidade de Picardie. Discorrendo sobre a multiplicidade de formas e de lugares da criação teatral contemporânea, Bident sugere, em seu texto, uma nova definição ao criar a noção que chamou de "o teatro atravessado".

Qual é esse teatro que nós podemos qualificar de "atravessado"? É a visão puramente abstrata de um espaço de representação em que intervêm corpos e linguagens. Por conseguinte, esse teatro pode ter lugar, concretamente, em teatros, mas também em museus, casas, galerias, porões, armazéns, fábricas desativadas ou não, hospitais, tendas, centros comerciais, praças públicas, ruas, em no man's lands, pedreiras, praias, rios, margens dos rios, barcos, ônibus, em estacionamentos, piscinas, banheiros, telas... A lista, evidentemente, não está encerrada. Ela confirma, se necessário for, o caráter ilimitado do campo da representação (Bident, 2016, p.51-52).

Um teatro cada vez mais atravessado por outras linguagens, artes e novas tecnologias. Neste caso, literalmente falando, "a cena é atravessada por cabos, por fluxos, por drones, ondas, telas. Os processos eletrônicos jogam com a recepção e particularmente com a percepção dos espectadores” (Bident, 2016, p.52).

\section{Um "projeto artístico atravessado": \\ linguagens, alteridade, criação, diferenças...}

O que é cenografia hoje? A mudança constante de percepção do corpo, do espaço, do tempo e do significado.

(Nesreen Hussein, 2015)

Inspirado pela definição de Bident, apresentei a proposta da atividade prática elaborada durante o período. Os/as estudantes precisavam criar, desenvolver e 
executar um "projeto artístico atravessado", que, mediado pela tecnologia, investisse no "atravessamento," na mistura de linguagens e manifestações. Possibilidades diversas de atravessamentos, como as artes plásticas, dramaturgia, dança, performance, instalação, intervenção, fotografia ou vídeo, por exemplo, puderam ser exploradas. Uma proposta que investigasse espacialidades, dimensões e relações com a vida. A ambientação cênica e/ou o figurino deveriam ser elementos determinantes, de modo que contribuíssem de forma significativa na escolha da concepção artística.

Correa (1997) afirma que aprender é um processo que depende de nós mesmos, de nossa atitude mental, e ensinar implica encorajar cada estudante até seu próprio julgamento. Uma nova realidade social exige uma reorientação que leve em conta a realidade dos processos de ensino e dos sujeitos envolvidos, estudantes e docente.

Nesse sentido, foi solicitado que também levassem em consideração, para a definição das propostas artísticas, seus desejos, sentimentos, vivências e estado de espírito momentâneos, reconhecendo-se "como sujeito do pensamento e do sentimento e, por outra parte, como alguém chamado a ver, na realidade externa: a beleza, o enigma, a sugestão, o símbolo, a sutileza, o risível, a ambiguidade, o sublime, o trágico" (Perissé, 2009, p.53). Os projetos demonstravam concepções variadas, e os temas possuíam relação com o presente e com o espaço habitado, além da acessibilidade aos materiais e equipamentos para execução.

As atividades práticas foram desenvolvidas pelos/as estudantes assincronamente e apresentadas, para toda a turma, nos encontros síncronos, nos quais ocorriam o (com)partilhamento das experiências, relato das dificuldades identificadas, sugestões e comentários. Para mim, as etapas práticas eram também um grande desafio, visto que, nas aulas presenciais, essas tarefas são elaboradas, em grande parte, no ateliê/sala de aula.

Trabalhar no ateliê garante um acompanhamento mais propositivo por parte do/a professor/a e assegura, também, condições materiais e espaciais igualitárias. Mesmo com todo o sucateamento e condições financeiras adversas, na universidade os/as discentes possuem acesso a equipamentos, utensílios, 
ferramentas, programas de computador e materiais básicos de desenho, pintura e maquete. Um espaço físico adequado com iluminação, bancadas e pranchetas são igualmente importantes. Por outro lado, no modelo remoto, não é garantida a equidade das circunstâncias materiais e espaciais. Deve-se tomar cuidado e estar atento, portanto, para que as diferenças não provoquem maiores desigualdades no desempenho dos/as estudantes.

Pensamos, então, coletivamente, diversas possibilidades do emprego de softwares, tecnologias e técnicas artísticas para a execução das tarefas, de modo que todos e todas fossem acolhidos/as. Os/as discentes puderam escolher, dessa maneira, as soluções mais apropriadas dentre as quais tivessem acesso, domínio ou que melhor atendessem à proposta apresentada, adequando-se à realidade de cada um/a. Criava-se, assim, um movimento dialógico e de construção coletiva visando ao fortalecimento dos vínculos, laços e de escuta, interrogando modos autoritários e assimétricos de lidar com o outro. Um compromisso e uma "razão ética" (Mèlich, 2006) atenta à palavra do outro. Atenta à alteridade. Atitude que contribui para romper com uma perspectiva epistemológica, historicamente construída, que coloca o/a estudante no lugar de quem apenas aprende, de quem precisa ser capacitado, formado. E, o professor, no lugar de quem somente ensina!

Com resultados igualmente satisfatórios, foram utilizadas diferentes técnicas na criação das pranchas de referências, um mural/painel composto por elementos visuais (fotos, ilustrações, objetos, formas, texturas, cores, palavras etc.), que traduz a essência do projeto. Softwares de edição de imagens, como o Adobe Photoshop e Adobe Illustrator, o aplicativo para tablet/celular Canva, além de colagens e composições criadas com objetos e materiais auxiliaram os/as estudantes em suas criações. 
Figura 1 - Prancha de referências da estudante Darlene Maravilha, criada no Canva Aplicativo para tablet/celular

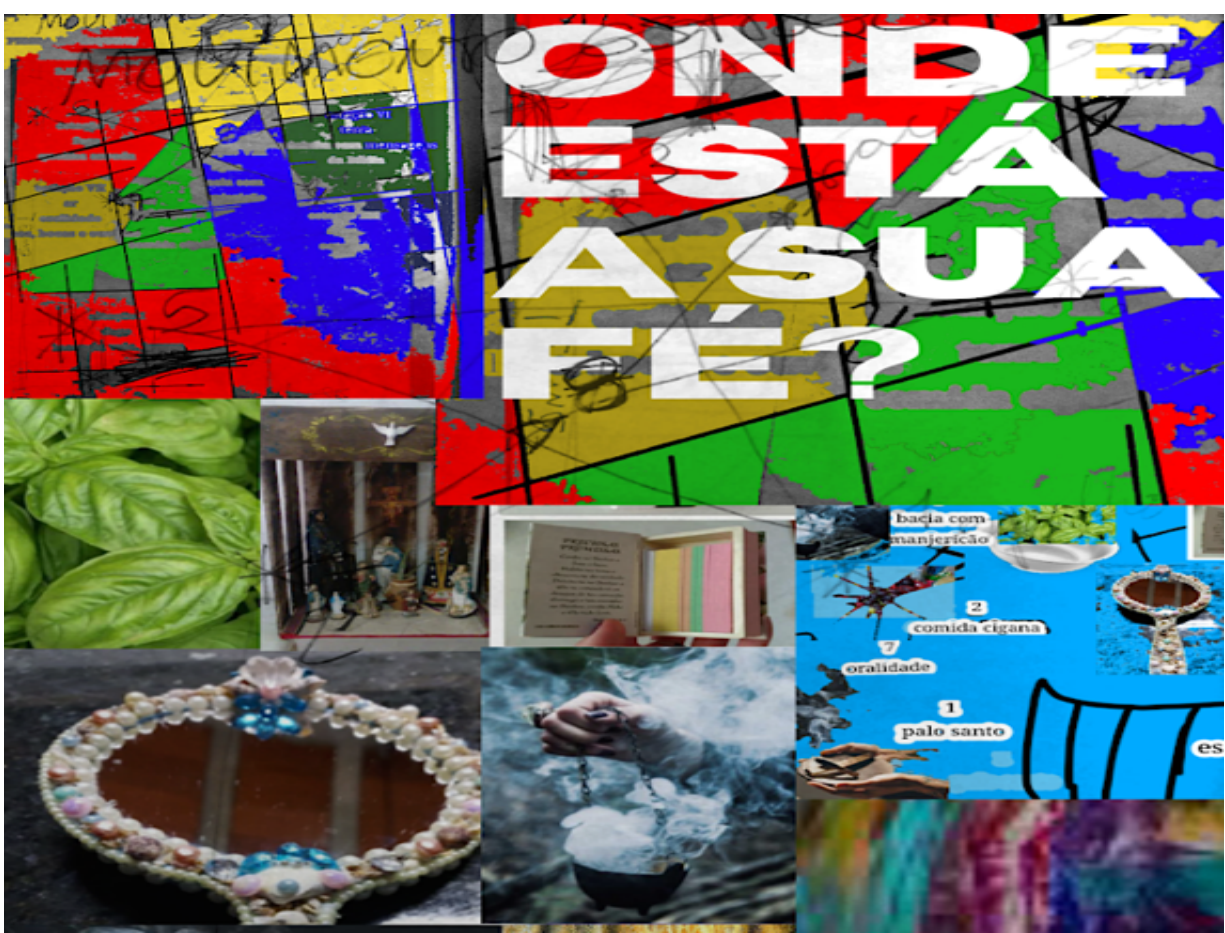

Figura 2 - Prancha de referências: Fronteiras - Autor: Victor Aragão

O estudante fotografou uma composição feita com os materiais que foram utilizados na instalação artística e manipulou a imagem digitalmente no Photoshop, inserindo as figuras de referência

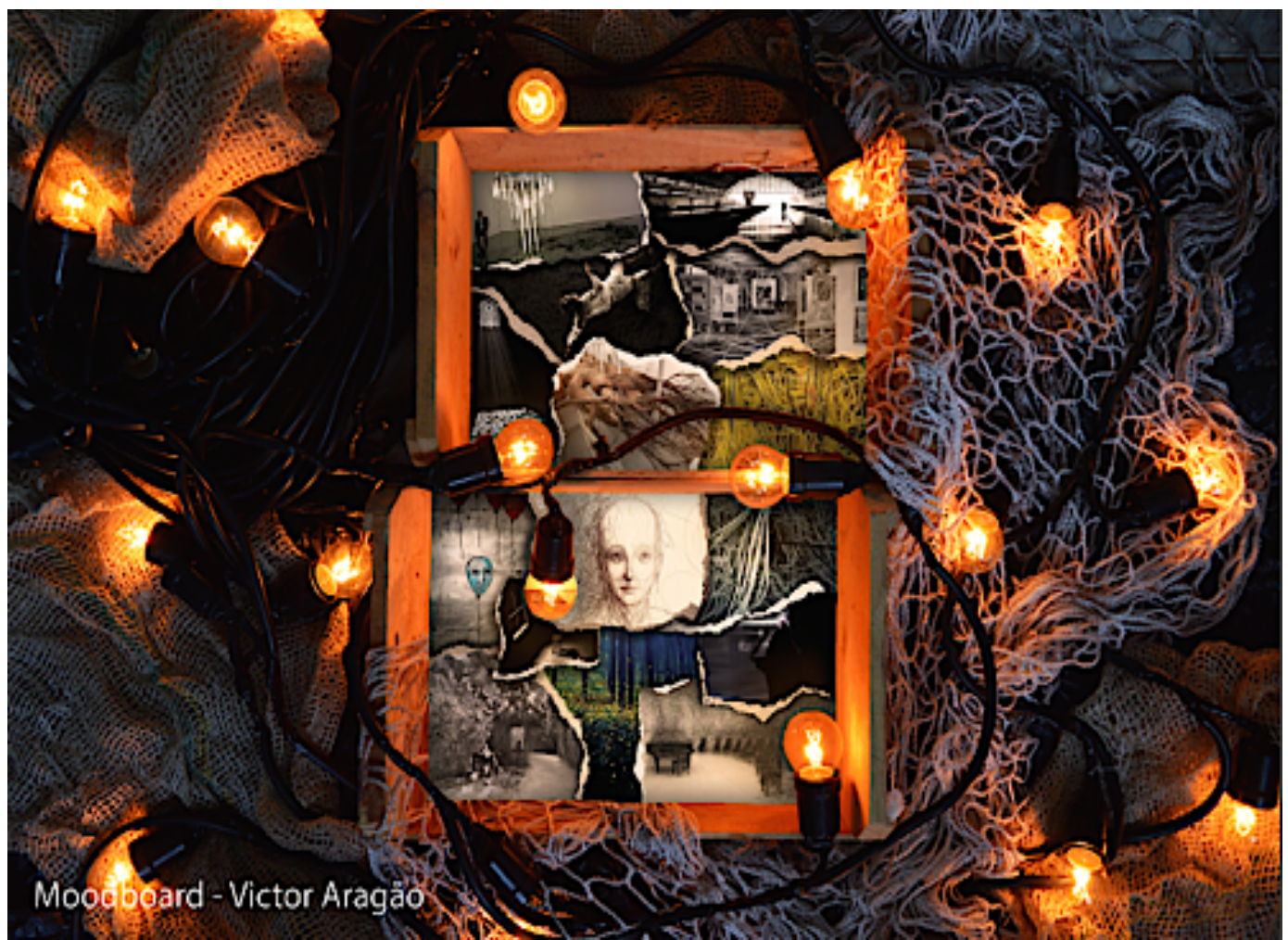


Figura 3 - O estudante Victor Aragão fotografando, sobre uma escada, a composição criada com sobras de materiais cenográficos que tinha em casa, utilizada como imagem base da sua prancha de referências

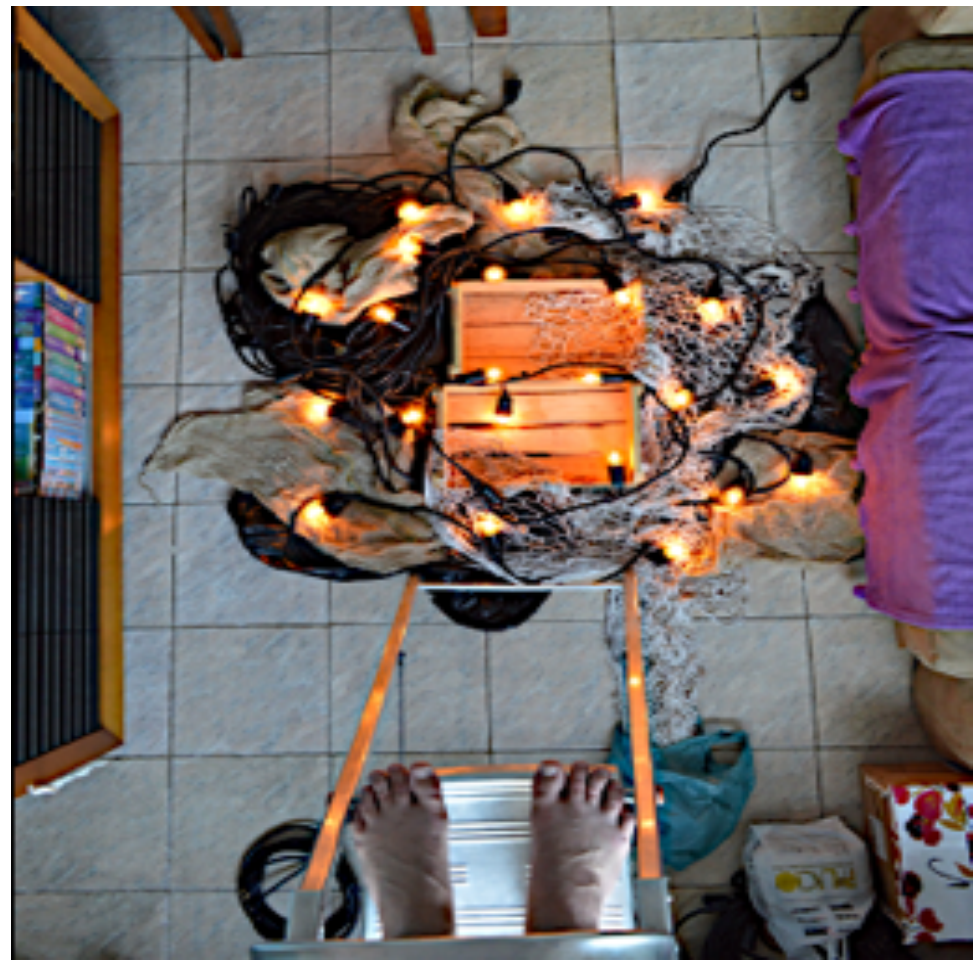

Figura 4 - Detalhe da prancha de referências da estudante Ana Clara Barroso.

Sobre uma base rígida, a estudante realizou uma colagem a partir de imagens impressas e fios vermelhos de lã

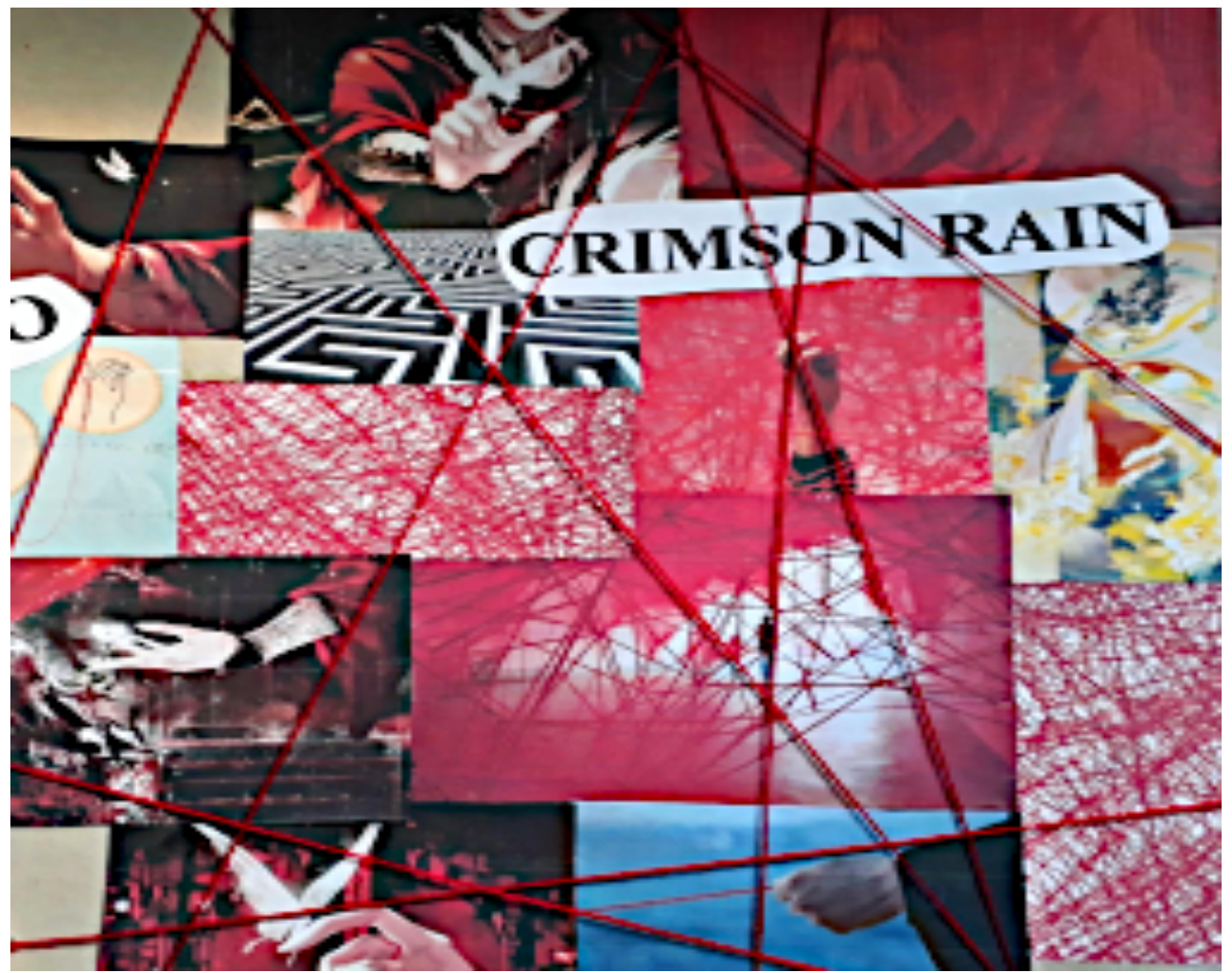


Em relação à escolha do local para a realização do projeto, requisitou-se que os/as estudantes explorassem o território ao seu redor, sentissem o potencial dos ambientes, fotografassem e imaginassem o que poderia ser criado a partir do espaço onde o isolamento social fosse respeitado; requisitou-se, também, que procurassem "vê-lo, não como é, mas como pode ser quando a marca do seu trabalho permeá-lo" (Howard, 2015, p.44). A apresentação das fotografias, nos encontros síncronos, permitiu a abordagem e discussão de aspectos como enquadramento, angulação, perspectiva, luz e pontos de interesse.

Após a definição do espaço, o próximo desafio foi "compor e colorir o local com figuras e formas" (Howard, 2015, p.125). Segundo Pamela Howard (Howard, 2015, p.125), os objetos, elementos e materiais "devem ser posicionados em um relacionamento com o espaço e de uns com os outros, para terem eloquência e significado."

Nesse sentido, uma técnica simples e acessível a todos/as foi aplicada no desenvolvimento dos croquis. Tomando como base um determinado enquadramento, os esboços foram realizados em papel manteiga ou vegetal, sobre a imagem do ambiente. Procedimento prático e barato para executar os estudos de composição e cor, sem demandar grandes recursos.

Figura 5 - Estudo de composição do estudante Victor Aragão
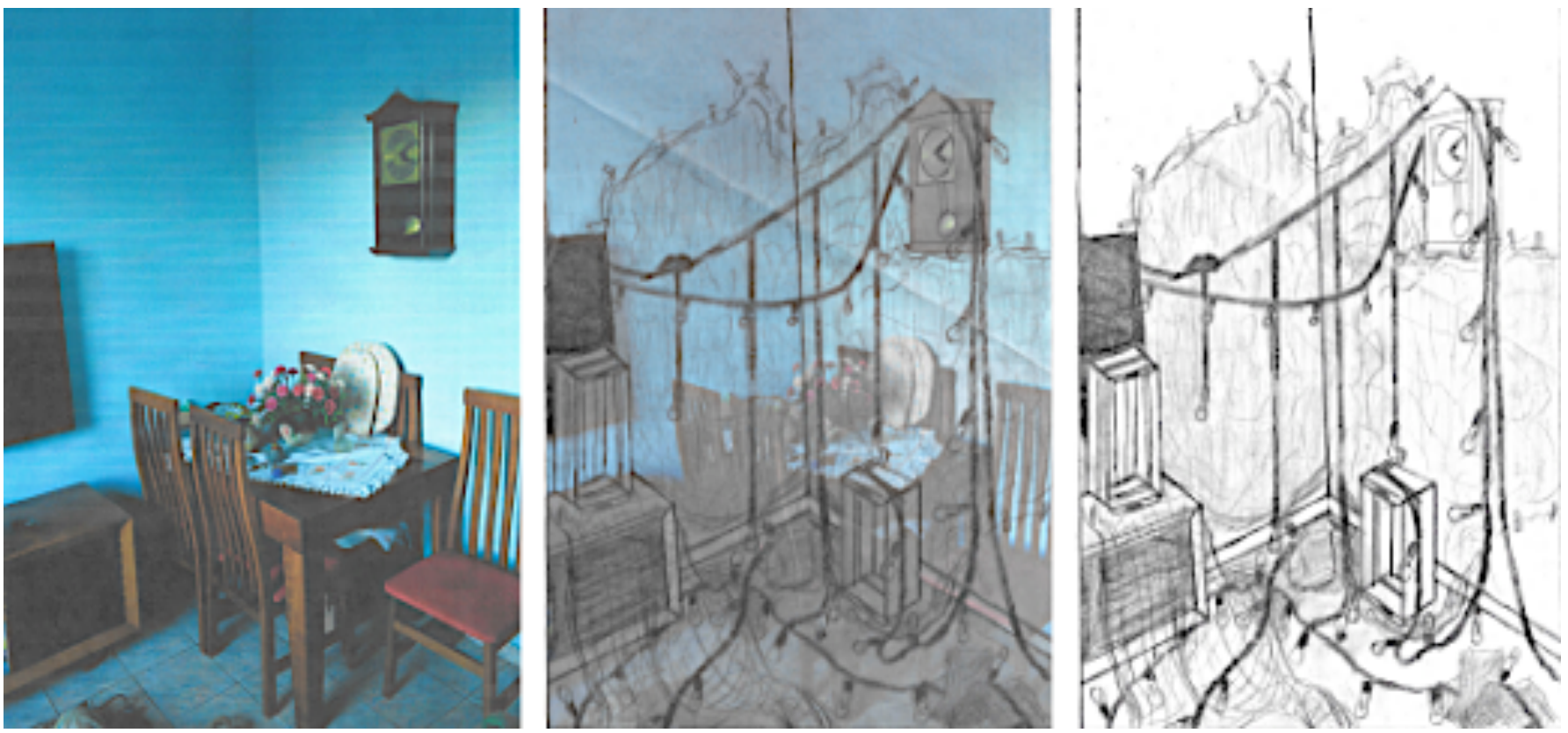
Com a definição do croqui, os/as estudantes finalizaram a apresentação do projeto na técnica mais adequada à sua realidade e proposta artística, além da listagem das intervenções, objetos e materiais necessários para sua execução. Uma técnica que transcendia a ideia mesma de técnica e incorporava uma dimensão poética, no campo do sensível e da experiência (Larrosa, 2011). Um aprender-ensinar não como competência ou domínio; um aprender-ensinar enquanto experiência, como algo que provoca pensar(-se), parar, prestar atenção... ao que se vê, ao que se pensa, ao que nos acontece.

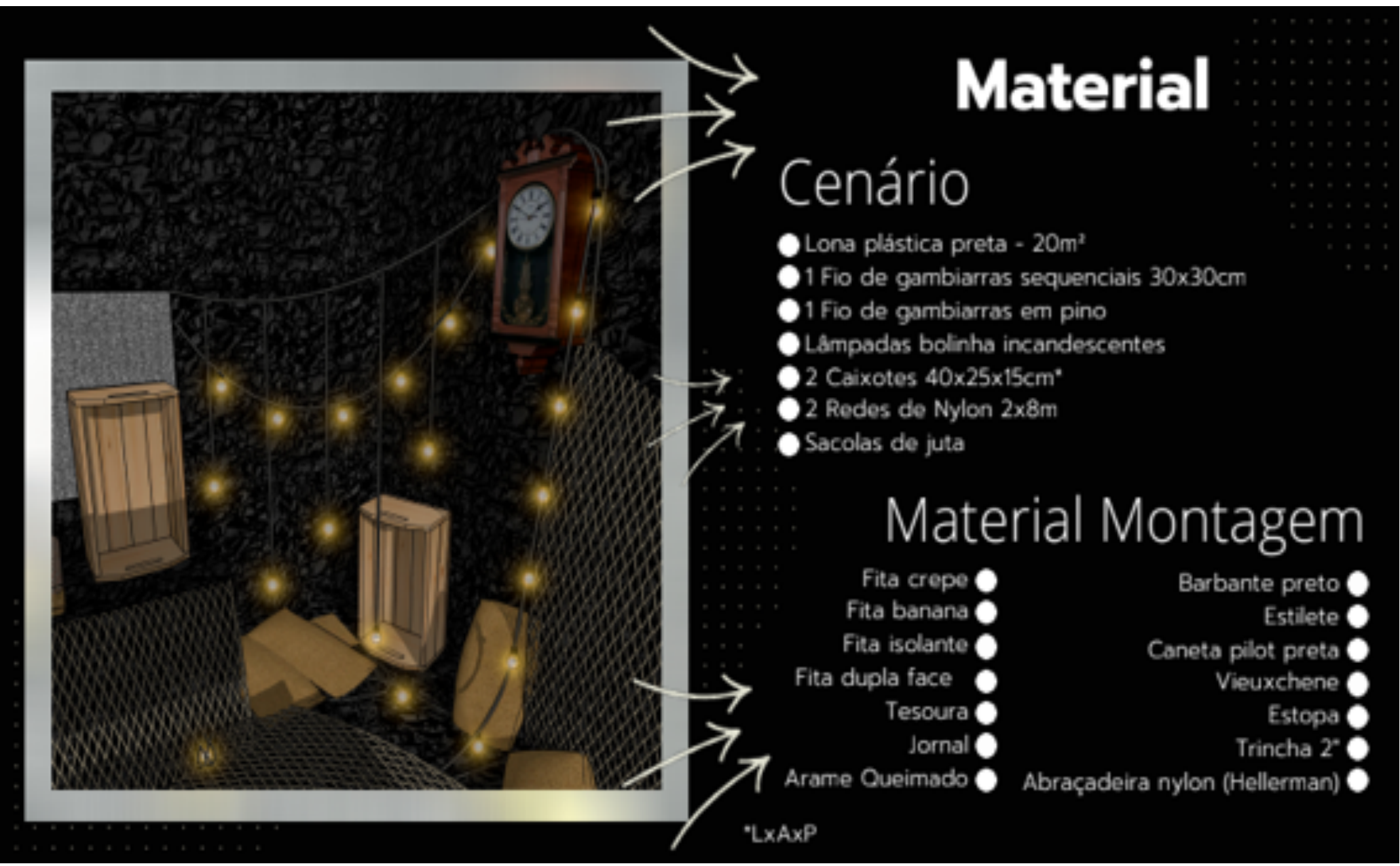


Figura 7 Quadro do vídeo-poema Fronteiras

Após a realização da instalação cenográfica, o estudante Victor Aragão produziu diversas fotografias e montou, com as imagens, um vídeo-poema.

Link do trabalho: https://youtu.be/XdY1KHcdI2I

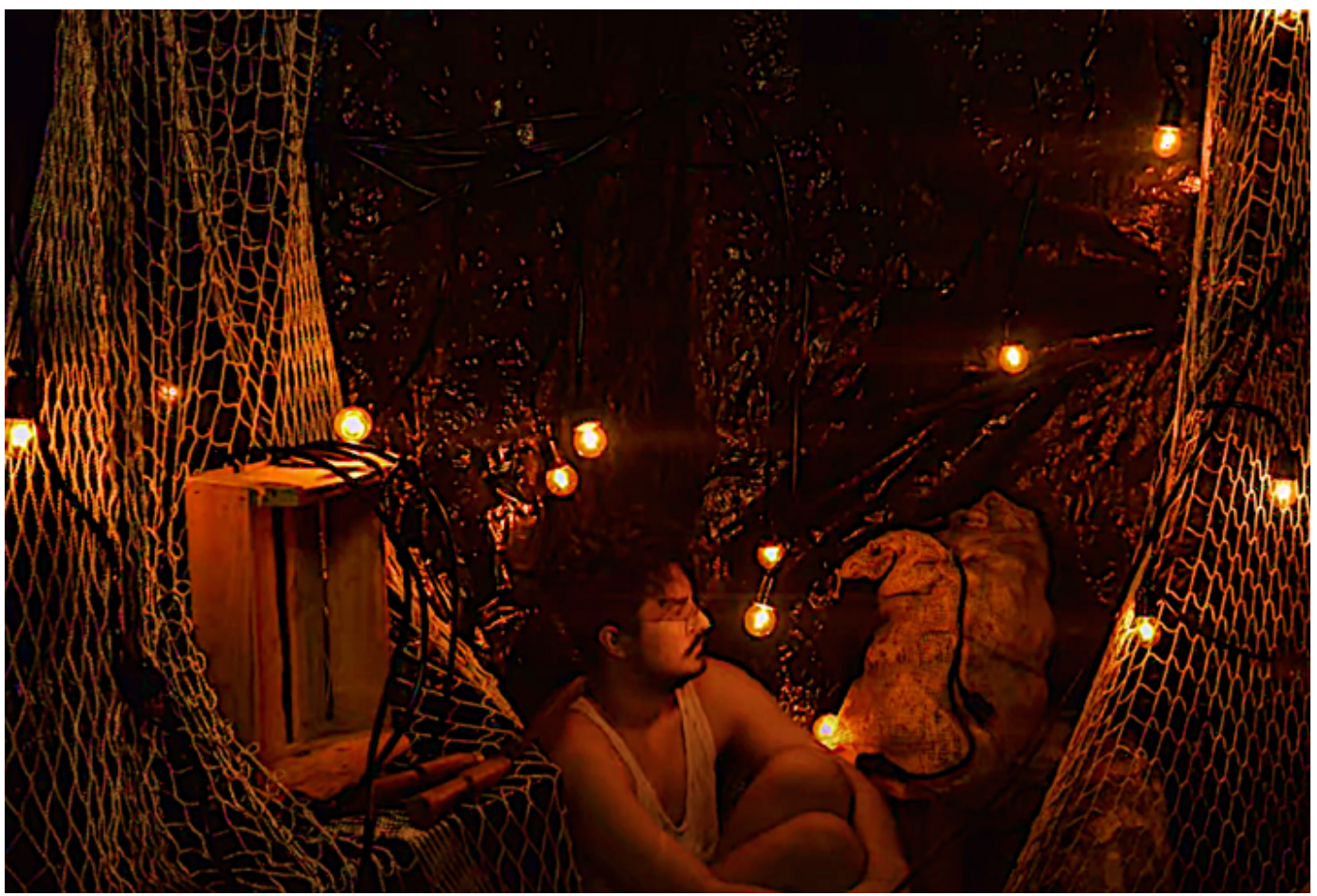

Figura 8 - A estudante Ana Clara Barroso criou uma instalação artística com fios vermelhos no terraço de sua casa para uma performance de dança.

À direita os croquis de figurino, realizados em aquarela e tinta guache.
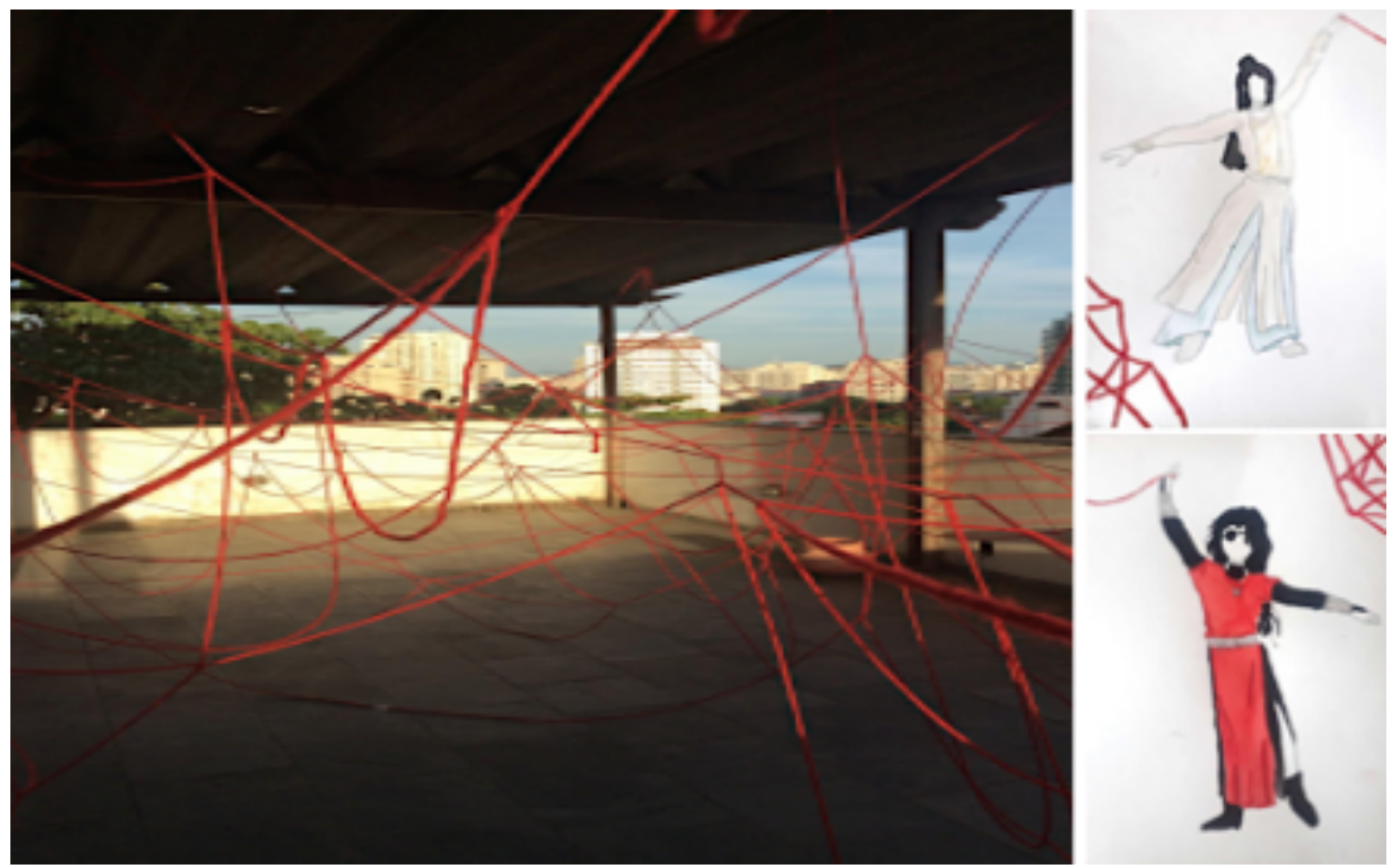
Figura 9 - A estudante Luma Wysykowska criou clipes musicais para o álbum O último fim de semana antes do fim do mundo, da banda Mulheres que correm com os loucos, da qual faz parte. As músicas foram produzidas no início da pandemia e os clipes, gravados por smartphones em uma estética Lo-fi, durante o período das aulas. Nas imagens à esquerda, o croqui da cena, e à direita, o print do quadro do vídeo. Para a execução dos storyboards a estudante trabalhou sobre fotografias, realizando os croquis digitalmente, em um software de desenho
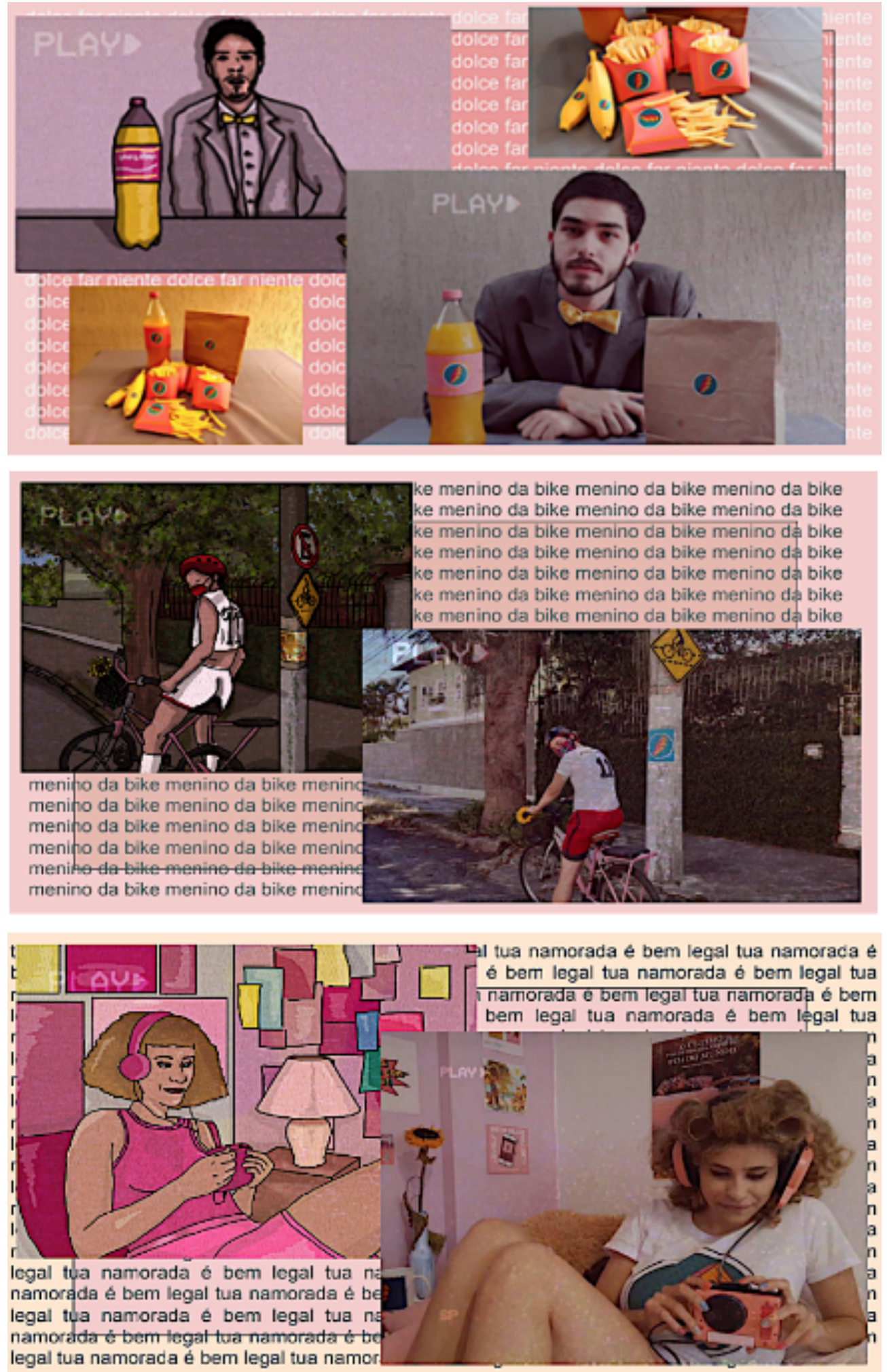
Figura 10 - Detalhes dos figurinos, cenografia e adereços produzidos pela estudante Luma Wysykowska para a gravação dos clipes.
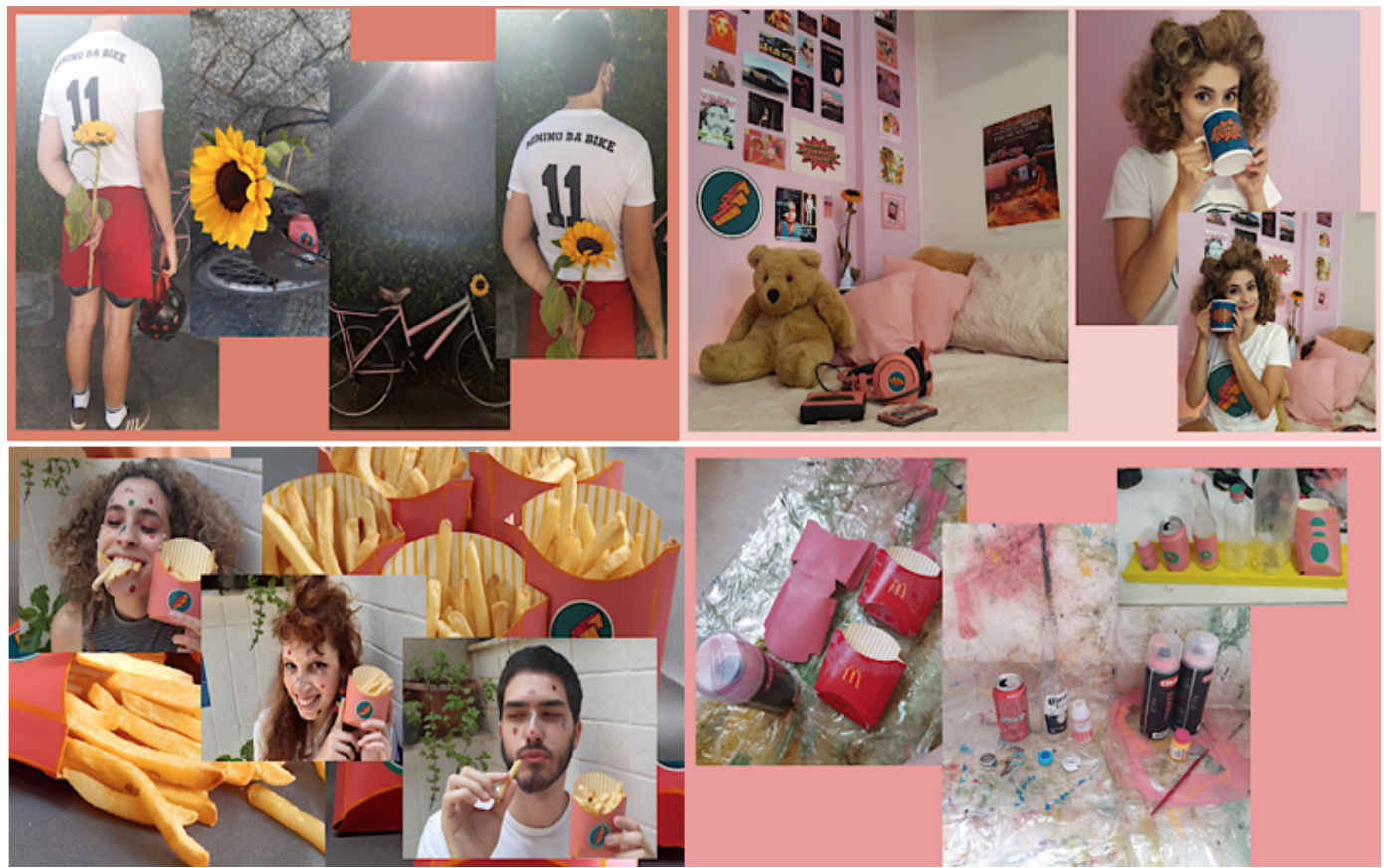

Figura 11 - $O$ estudante Halyson Félix criou propostas de figurinos para sua persona drag?, tendo como inspiração a personagem Agrado, do filme Tudo sobre minha mãe, de Pedro Almodóvar, a Julieta, de Shakespeare e a Selminha, de Um beijo no asfalto, peça de Nelson Rodrigues. Na apresentação dos croquis foram utilizadas técnicas de pintura em aquarela e guache, colagem e objetos em modelo reduzido
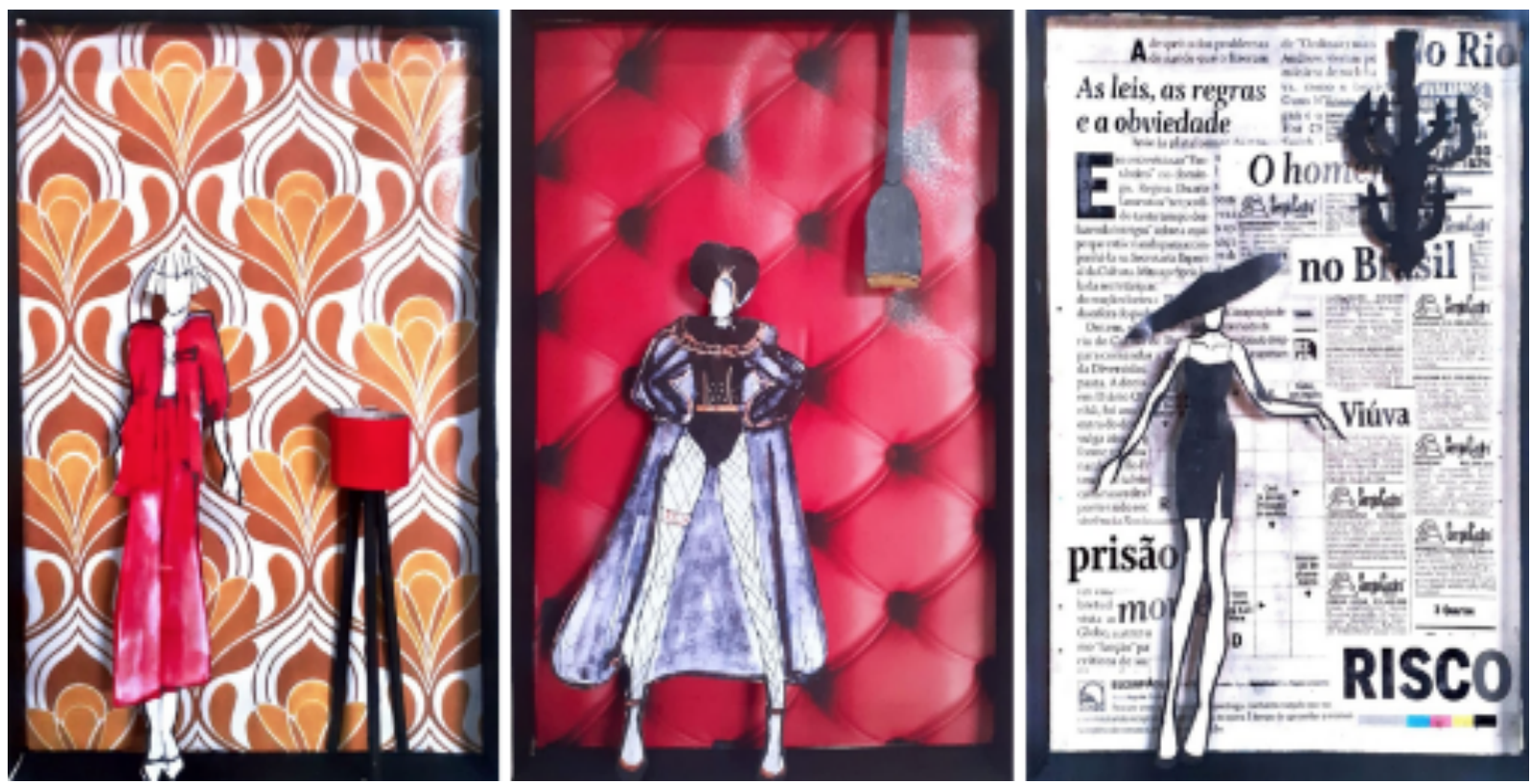

Drag Queens são personagens criadas por artistas performáticos que se vestem e se comportam de forma estilizada, com uma expressão de gênero exageradamente feminina. 
Através de brechas e fendas, foi possível criar possibilidades, oportunidades e aberturas em tempos de ensino remoto, sem deixar de lado a responsabilidade, a ética e o engajamento. Entretanto, é desafiante pensar o ensino em um modelo educacional que não previu a inclusão digital. É urgente o domínio das novas tecnologias para o aperfeiçoamento de métodos e práticas de ensino, além do respeito à autonomia dos/as docentes na escolha das metodologias que melhor conversem com o conteúdo de suas disciplinas. Mas, a ausência de políticas públicas comprometidas com esses desafios educacionais e pedagógicos provocam e aprofundam desigualdades sociais, econômicas, educativas e de vida.

Não por acaso, Cássia Geciauskas, Joaquim Sofiato e Vinícius Catão, parafraseando o filósofo grego Heráclito, afirmam, interrogando-nos:

não há como ser tudo igual, pois nem nós seremos o mesmo, nem o mundo será mais o mesmo. Se tudo continuar igual, é muito provável que não tenhamos compreendido aquilo que o momento atual nos impôs viver. Se faz necessário, então, reavaliar os desafios impostos e, sobretudo, a nós mesmos e o nosso lugar no mundo (2020, p.163).

Como fazer presença no mundo? Como fazer presença neste mundo? A abertura à experiência pode estremecer a vida? Pode nos inscrever em modos outros de sentir, de entender, de atuar, de pensar e de estar ética, política e poeticamente presentes?

Considerações finais

Ou sobre nós mesmos a partir de um vivido entre nós...

É no exercício de sua autoria que o docente vai tecendo os fios da metodologia prática-teoria-prática no seu cotidiano.

Por fim, é no ato de criar mundos possíveis, e só nele, que repousamos nossa esperança.

(Ana Carolina Sales; Débora do Carmo; Jeane Araújo; Karina Santos, 2020)

As atividades acadêmicas e letivas do período excepcional terminaram no dia dezenove de dezembro de 2020. Diante do caos, impossibilidades e medos iniciais, acredito que as experiências vivenciadas durante o semestre foram, de maneira geral, surpreendentes. Em uma narrativa escrita no mural da sala virtual, o 
estudante José Carlos dos Santos relatou:

Penso que o andamento das atividades durante o período de isolamento foi, por si só, muito positivo. Produzir em meio a um pesadelo soa quase impossível, e seguir botando fé na arte beira a insanidade. As aulas eram para mim, ainda no início do ano, o combustível que faltava para voltar a materializar qualquer ideia que me tirasse do medo em que estava mergulhado, frente às incertezas do futuro. Agora que terminou, vejo que foi mil vezes melhor do que esperava. E que bom!

A aposta em metodologias (inter)ativas favoreceu o protagonismo dos/as estudantes através de estratégias colaborativas e cooperativas, proporcionando um espaço de interatividade com saberes que fizeram sentido e, por conseguinte, despertaram o desejo de conhecimento. A autonomia na escolha dos temas, o aprendizado através de discussões coletivas e os conteúdos adaptáveis proporcionaram uma prática pedagógica, pensada para o ambiente virtual, que fosse mais do que a simples utilização de ferramentas tecnológicas.

A necessidade de explorar o mundo virtual, antes somente visitado, exigiu versatilidade para desenvolver e delinear o plano de atividades em condições extraordinárias. As inovações propiciadas pelas tecnologias digitais apontaram novas perspectivas, com diferentes maneiras de construir o conhecimento. "Ressignificar o conceito de ensino e criar um novo papel para o educador e também aos estudantes, é o desafio trazido pelas transformações tecnológicas" (Gandin; Júnior, 2021, p.502).

Será possível mantermos as antigas posturas quando voltarmos às aulas presenciais? Difícil imaginarmos a disponibilização de textos impressos para serem copiados, por exemplo. Ou a proibição de celulares em sala de aula, com fins acadêmicos. Foi revelador as vantagens do emprego das plataformas digitais para a disponibilização de conteúdo e material didático, além do uso da internet como meio de aprendizado, pesquisa, compartilhamento de ideias e de conhecimento. Aos/às professores/as, fica o papel de orientar os/as estudantes em meio ao universo de possibilidades, não como tutores/as, mas como mediadores/as que estimulam a autonomia e o senso de responsabilidade na utilização dos meios digitais.

Nesta perspectiva, procurei me colocar, desde o princípio, como um 
professor presente, atento e que convida... convida a pensar, a conversar, a conhecer; a arriscar(-se), a experimentar(-se), a acreditar(-se). E sentidos outros foram se fazendo presentes na ausência dos encontros presenciais, na universidade. A estudante Luma Wyzykoska escreveu:

Foi ótimo ter uma motivação para voltar a produzir, mesmo de maneira remota. Acho que o ensino presencial nunca vai ser substituído, mas dentro do que tivemos de possibilidades, fiquei bastante satisfeita com os resultados.

Entretanto, não podemos desconsiderar as grandes vulnerabilidades existentes. Praticamente quarenta por cento dos/as discentes matriculados/as trancaram a disciplina por questões familiares, problemas de saúde, falhas na conexão de internet, falta de equipamentos adequados e dificuldades com a realização das atividades de maneira remota. A substituição repentina do ensino presencial para o modelo à distância acentuou as lacunas do sistema educacional e a desigualdade da inclusão digital, reafirmando a relevância do campus universitário como local potente de igualdade. A narrativa do estudante Felipe Simas deixa evidente as adversidades que muitos vivenciaram:

Tenho muita dificuldade com o modelo EAD. Ainda estou me acostumando a aprender através do ensino a distância, enquanto nossas vidas viraram de cabeça para baixo. Gosto muito do seu modelo de aula, com conteúdo que inicia e conclui o pensamento na mesma aula. Porém, sinto falta de fazer as coisas em turma, no horário de aula. Para mim é ótimo como estímulo. Tive muita dificuldade com a organização do tempo, não soube conciliar bem a faculdade, o trabalho e a vida em casa. Voltei pro interior, estou trabalhando à noite e meus horários são péssimos. Fazer a maquete foi uma loucura, tudo que podia acontecer, aconteceu. Meu estilete estava sem lâmina, não tinha papel para cortar, a impressora quebrou, as colas tinham passado da validade e não colavam nada. Só possuía uma cola de isopor. Peguei aquele papel duro que vem atrás dos blocos de folhas de desenho, cortei no tamanho das paredes usando uma tesourinha de unha (passando várias vezes a ponta para cortar ou marcar o vinco da dobra), escolhi a textura do chão e das paredes, todos os objetos, testei e tentei fazer tudo mais ou menos numa escala. Entretanto, apesar dos percalços, foi ótimo, eu não me estressei em momento nenhum. Consegui fazer tudo com calma. Foi muito bom de fazer.

O trabalho na sala de aula/ateliê propicia o acompanhamento e desenvolvimento de certas etapas de um projeto, como maquete, plantas e 
desenhos técnicos, que no ensino remoto, para sua efetiva realização, ficam condicionadas ao acesso do/a estudante à equipamentos, materiais e espaço físico adequados. O comentário da estudante Lara Aline também se relaciona com esta adversidade:

Como se apropriar melhor de ferramentas digitais (para expressão, comunicação, criação, representação) foi o processo que mais identifiquei carência e que penso merecer mais atenção, ainda mais considerando a digitalização das coisas no mundo pós-covid19.

A observação da estudante é relevante. O domínio das ferramentas digitais é um aspecto importante que merece, sem dúvida, atenção. Porém, apenas trinta por cento dos/as discentes possuíam computador com algum software de desenho, desenho técnico, modelo 3D ou edição de imagens. A desigualdade tecnológica impossibilita, desse modo, a oportunidade de desenvolver um trabalho mais direcionado e uniforme com toda a turma.

Mesmo com o auxílio de softwares, pode ser difícil trabalhar adequadamente planta baixa, vistas e desenho técnico sem prancheta de desenho, régua paralela ou, no mínimo, uma mesa ou bancada adequada. Essas etapas correm o risco de ficarem negligenciadas, dependendo das condições materiais dos/as estudantes. Uma questão a ser enfrentada nos próximos períodos, enquanto durar o modelo remoto, nas disciplinas eletivas cujos conteúdos de ensino exijam tais processos.

Nesse sentido, tornou-se urgente a necessidade da integração de todos/as, levando em consideração a realidade dos/as estudantes e das instituições de ensino. É imprescindível a luta por políticas de inserção social e digital que possibilitem a inclusão educacional, garantindo a qualidade e reafirmando o conceito de educação como um direito público.

No entanto, para potencializar as possibilidades existentes, nessa primeira experiência on-line, como já mencionado, os/as discentes ficaram livres para escolher as soluções possíveis, de acordo com suas realidades, e que melhor se adaptassem às demandas dos projetos. Procurei, também, estar atento e sensível ao tempo e ritmo de cada um/a, levando em conta o período de excepcionalidade que vivenciávamos. As palavras da estudante Wanessa Oliveira reconhecem estes cuidados: 


\begin{abstract}
Achei muito proveitoso todo o processo. Não sabia como apresentar um projeto adequadamente. Compreender como isso se organiza numa apresentação (de ideias, de justificativas, de apresentação, de orçamento) foi algo valioso. Estou usando bastante e me sinto bem mais segura. O ritmo foi bom, me senti muito respeitada/não pressionada em relação à apresentação dos exercícios propostos. Deu tempo de desenvolvê-los no meu ritmo. Não me sentir sobrecarregada foi fundamental para que não me perdesse. Tinha receio de que a equipe docente pensasse que só porque estávamos em casa não teríamos demandas (e elas às vezes são mais pesadas justamente porque não podemos desviar delas), mas os exercícios foram bem possíveis sem que se perdesse a qualidade de criação. Muito agradecida pelo cuidado com nossa saúde mental. Isso é algo que eu sempre ficava repetindo como um disco arranhado.
\end{abstract}

Nestes tempos difíceis nos quais estamos próximo, mas, ao mesmo tempo, longe; tempos em que trabalhamos na presença a partir da não presença, ou de uma nova presença, considero importante a aposta em relações das quais a empatia, o afeto, a escuta e o diálogo sejam constitutivos. Afinal, o que podem gestos, muitas vezes mínimos, de atenção às singularidades e diferenças? O que pode uma relação de aprendizagem aberta aos encontros? O que podem os encontros?

\title{
Referências
}

ARAÚJO, Jeane; DO CARMO, Débora de lima; SALES, Ana Carolina; SANTOS, Karina. Pesquisa em suspensão e a estética de habitar as perguntas sobre formação. In: Tania Chalhub; Tiago da Silva Ribeiro (Orgs.) Reflexões de um mundo em Pandemia. Educação, comunicação e acessibilidade. Rio de Janeiro: Ayvu, p.553-576, 2020.

BIDENT, Christophe. O teatro atravessado. Art - Art Research Journal / Revista de Pesquisa em Artes, v.3, n.1, p.50-64, 2016. Disponível em: https://periodicos.ufrn.br/artresearchjournal/article/view/8504

Acesso em: 25 out. 2020

BRITO, Talamira Taita Rodrigues; MUSSI, Amali de Angelis. Autonomia universitária em tempos de pandemia: desafios e proposições das universidades estaduais baianas para a garantia do acesso e permanência à educação de qualidade socialmente referenciada. In: Elenita Conegero Pastor Manchope; Andréa Araújo do Carmo; Fabiano Gonçalves Costa; Kathia Marise B. Sales; Soraia Cristina Tonon da Luz; Vera Maquêa (Orgs.) Educação superior na (pós)pandemia: práticas em construção em universidades brasileiras. Cascavel: Edunioeste, p.47-70, 2020.

CARVALHO NETA, Raimunda Nonata Fortes Carvalho; SOUZA, Débora Batista 
Pinheiro. Mediação docente via webconferência em tempos de isolamento social: desafios e possibilidades na pós-graduação. In: Elenita Conegero Pastor Manchope; Andréa Araújo do Carmo; Fabiano Gonçalves Costa; Kathia Marise B. Sales; Soraia Cristina Tonon da Luz; Vera Maquêa (Orgs.) Educação superior na (pós)pandemia: práticas em construção em universidades brasileiras. Cascavel: Edunioeste, p.207218, 2020.

CORREA, Charles. Learning from Ekalavya. In: Martha Pollak. Education of the architect. Cambridge: MIT Press, 1997.

DA LUZ, Soraia Cristina Tonon; MAQUEAA, Vera. O professor universitário e a pandemia de Covid-19: é possível se reinventar em meio ao caos? In: Elenita Conegero Pastor Manchope; Andréa Araújo do Carmo; Fabiano Gonçalves Costa; Kathia Marise B. Sales; Soraia Cristina Tonon da Luz; Vera Maquêa (Orgs.) Educação superior na (pós)pandemia: práticas em construção em universidades brasileiras. Cascavel: Edunioeste, p.101-117, 2020.

DUARTE, Marcos Machado; FISS, Dóris Maria Luzzardi. Participação. Textura, Canoas, v.23, n.53, p.488-489, 2021. Disponível em:

http://www.periodicos.ulbra.br/index.php/txra/article/view/6348

Acesso em: 12 abr. 2021

EGAN, Kieran; MCEWAN, Hunter. La narrativa en la enseñanza, el aprendizaje y la investigación. Buenos Aires: Amorrortu, 2005.

GALVÃO, Ana Carolina; SAVIANI, Dermeval. Educação na pandemia: a falácia do "ensino" remoto. ANDES-SN, janeiro, 2021.

GERALDI, João Wanderley. A aula como acontecimento. São Carlos: Pedro \& João Editores, 2010.

GUIMARÃES, Rafael Siqueira de; RIBEIRO, Everton. "Pra que esse drama?": uma experiência de ensino de Teatro entre professores em formação. Urdimento Revista de Estudos em Artes Cênicas, Florianópolis, v.3, n.36, p.63-84, 2019. Disponível em:

https://periodicos.udesc.br/index.php/urdimento/article/view/15808

Acesso em: 15 mar. 2021

HOWARD, Pamela. O que é cenografia? São Paulo: Edições SESC SP, 2015.

HUSSEIN, Nesreen. In: Pamela Howard. O que é cenografia? São Paulo: Edições SESC SP, 2015, p. 20.

LARROSA, Jorge. Experiência e alteridade em educação. Revista Reflexão e Ação, Santa Cruz do Sul, v.19, n.2, p.04-27, jul./dez., 2011.

LIMA, Camila Machado. Infâncias e formação docente: gestos, sentidos e começos. Childhood \& Philosophy, Rio de Janeiro, v.14, n.30, p.297-315, mai./ago., 2018. 
LISPECTOR, Clarice. Água Viva: edição com manuscritos e ensaios inéditos. Rio de Janeiro: Rocco, 2019.

MĖLICH, Joan-Carles. Transformaciones - tres ensayos de filosofía de la educación. Buenos Aires: Miño y Dávila, 2006.

MELO, Keite Silva de; PINTO, Maria de Lourdes de Melo; RIBEIRO, Caroline Monteiro. Diálogos afetivos e (trans)formativos em tempos desafiadores. In: Tania Chalhub; Tiago da Silva Ribeiro (Orgs.) Reflexões de um mundo em Pandemia. Educação, comunicação e acessibilidade. Rio de Janeiro: Ayvu, p.526-552, 2020.

MORAES, Marcia. Ser humana: quando a mulher está em discussão. Rio de Janeiro: DP\&A, 2002.

OLIVEIRA, Fabiane Lopes. Educação transformada em EAD durante a pandemia: quem está por trás dessa ação? In: Cristiane Brandão Augusto; Rogerio Dultra dos Santos (Orgs.) Pandemias e pandemônio no Brasil. São Paulo: Tirant lo Blanch, p.247-260, 2020.

OSTETTO, Luciana Esmeralda; SILVA, Greice Duarte de Brito. Arte na formação docente para a Educação Infantil: Procura-se. Poésis, Tubarão, v.12, n.21, p.185-203, 2018. Disponível em:

http://www.portaldeperiodicos.unisul.br/index.php/Poiesis/article/view/5902/3942 Acesso em: 15 abr. 2021

PERISSÉ, Gabriel. Estética \& Educação. Belo Horizonte: Autêntica, 2009.

RIBEIRO, Tiago da Silva. Ensino Remoto? Educação à distância? Vamos conversar sobre o trabalho do professor-pesquisador na pandemia! In: Tania Chalhub; Tiago da Silva Ribeiro (Orgs.). Reflexões de um mundo em Pandemia. Educação, comunicação e acessibilidade. Rio de Janeiro: Ayvu, p.451-509, 2020.

SKLIAR, Carlos. A escuta das diferenças. Porto Alegre: Mediação, 2019.

SOUZA, Bruna Betamin. Humanizar. Textura, Canoas, v.23, n.53, p.476-477, 2021. Disponível em: http://www.periodicos.ulbra.br/index.php/txra/article/view/6348 Acesso em: 12 abr. 2021

STRAUHS, Faimara do Rocio; TEDESCHI, Marcos Antonio. O Impacto do Ensino Remoto Emergencial na carga de trabalho dos discentes de um curso de Instituição Federal de Educação Superior. Revista Extensão em Foco, Palotina, n.23 (Especial), p.21-49, jun./2021.

Disponível em: https://revistas.ufpr.br/extensao/article/view/80524

Acesso em: 10 mar. 2021

VILARINHO JR, Ildo Ronan. Administração Energética. Textura, Canoas, v.23, n.53, p.450-452, 2021. Disponível em:

http://www.periodicos.ulbra.br/index.php/txra/article/view/6348

Acesso em: 12 abr. 2021 
Recebido em: 14/06/2021

Aprovado em: 26/09/2021

Universidade do Estado de Santa Catarina - UDESC

Programa de Pós-Graduação em Teatro - PPGT

Centro de Arte - CEART

Urdimento - Revista de Estudos em Artes Cênicas

Urdimento.ceart@udesc.br 